\title{
Depilling of Spun Polyester Fabric through Laundering with Detergent Containing Alkaline Cutinolytic Esterase
}

\author{
Taweeporn Sooksai, Hunsa Punnapayak, Sehanat Prasongsuk, and Usa Sangwatanaroj
}

\begin{abstract}
This research targets to remove fabric pill from spun polyester knitted fabric (pilling rate 1 out of 5 ) through laundering with a detergent containing alkaline cutinolytic esterase. After washing, fabric was graded for pilling rate, measured for color difference, and tested for weight loss and strength loss. Results indicated that fabric washed with detergent containing esterase had lower amount of pills (pilling rate 3-4) than that washed only with detergent (pilling rate $2-3$ ). In addition, the former also showed better color appearance than the latter. However, the fabric weight loss and strength loss after washing with detergent containing esterase were slightly higher than that washing with only detergent.
\end{abstract}

Index Terms-Fusarium sp., cutinolytic esterase, laundry detergent, spun polyester, fabric pill.

\section{INTRODUCTION}

Polyethylene terephthalate (PET) is a synthetic polyester fiber often used in textile industry (approximately 70\%) because of its outstanding properties including high strength and durability, light weight, resistance to wrinkle, high abrasion resistance, and easy to care for. However, frequent wearing and washing spun polyester fabric (made from staple or short fibers) can lead to pilling (small ball of loose fibers) or fuzzing (loose fibers) on fabric surface that causes unpleasant look.

This is because during wearing and washing, loose fibers start to push out from the fabric surface, and over time, abrasion causes entanglements of loose fibers and finally develops them into spherical bundles anchoring on the fabric surface, known as fabric pill. Due to fiber high strength, it is not easy to remove fabric pill from surface of polyester fabric via regular washing.

Three methods are suggested for pill removal or depilling, consisting of physical (shear/shave), chemical (alkaline treatment), and biological (enzymatic treatment) methods. Enzymes have been used effectively in textile industries as well as to assist the development and improvement of modern household and industrial detergents. Surface treatment with enzymes are related to the field of enzyme technology and the

Manuscript received August 8, 2017; revised November 5, 2017. This work was financial supported by Chulalongkorn University and the Department of Agriculture, Ministry of Agriculture and Cooperatives, Thailand.

T. Sooksai, H. Punnapayak, and S. Prasongsuk are with the Plant Biomass Utilization Research Unit, the Department of Botany, Faculty of Science, Chulalongkorn University, Bangkok, Thailand (e-mail: moferdream@gmail.com, phunsa@chula.ac.th, sehanat.p@chula.ac.th).

U. Sangwatanaroj is with the Department of Materials Science, Faculty of Science, Chulalongkorn University, Bangkok, Thailand (e-mail: usa.s@chula.ac.th). benefit of using enzyme is fast in reaction rate with highly specific reaction at mild condition.

Cellulase, lipase and protease enzymes have been widely used in various laundry detergent.Some research works have confirmed that cutinase, a lipolytic enzyme, can also be another choice for detergent [1]-[4] as well as for textile industries. Cutinase is known to catalyze the hydrolysis of polyester molecules at their ester bonds into carboxyl and hydroxyl groups. This reaction causes the decrease of the degree of polymerization of polyester chains, the weakness of fibers, and finally the removal of these fibers from polyester surface when additional mechanical action is applied.

Andersen et.al. patented a method to treat polyester fabric with a polyester hydrolytic enzyme, a terephthalic acid diethyl ester hydrolytic enzyme (ETE hydrolytic enzyme) and/or an ethyleneglycol dibenzyl ester hydrolytic enzyme (BEB hydrolytic enzyme) in the presence of detergents, in order to reduce pilling propensity and to improve color clarification [5]. Yoon et al. treated polyester fabric with polyesterase-a serine esterase and found improvements of fabric's hydrophilicity, oily stain release, pill and polyester size removal, and cationic dye binding. However, treated fabric showed a decrease of fabric luster [6]. In 2005, Mccloskey and Jump [7] attempted to remove pills from polyester fabric surface through bio-polishing process using cutinase as well as to treat 50/50 polyester/cotton fabric with cutinase and a compatible cellulase, and found successful pill removal results. Donelli et al. treated polyester surface with a lypolytic enzyme (commercial cutinase) in order to improve its surface hydrophilicity and found increases of wettability and dyeability of treated polyester materials [8]. In addition, Nimchua et al. found a high cutinolytic esterase produced from Fusarium solani after cultivation in a medium with initial $\mathrm{pH}$ of 11.0 at $25^{\circ} \mathrm{C}$ for 4 days and used it for surface treatment of polyester fiber [9]. Cutinases had also been used in laundry detergents for depilling of polyester fabric [10]. Nowadays, designs of novel enzymes with enhanced activity on synthetic polymer substrates are still being screened and selected for industrial applications, especially in detergent industry.

In this study, a local produced cutinolytic esterase powder was added into a commercial powder detergent and the detergent was used for laundering spun polyester knitted fabric that has a pilling rate of 1 (highest amount of pills) in order to study the effect of esterase in detergent on pill removal efficiency.

\section{MATERIALS}

Fabric for this study was a local produced red spun 
polyester knitted fabric with single jersey construction. The commercial detergent used in this work was an alkaline powder detergent (sodiumlauryl ether sulfate and alcohol ethoxylated), supplied by Unilever (Thailand) Co., Ltd. Cutinolytic esterase enzyme showed optimum activity at $\mathrm{pH} 9.0$ and temperature $35^{\circ} \mathrm{C}$ was produced from Fusarium falciforme PBURU-T5 at the Plant Biomass Utilization Research Unit, Department of Botany, Chulalongkorn University, and was used in this research.

\section{EXPERIMENTAL}

\section{A. Preparation for Pilling Sample}

Approximately $10 \mathrm{~cm}$ x10 $\mathrm{cm}$ or $1.3 \mathrm{~g}$ of fabric was mounted on polyurethane tube and placed in pilling box. Sample was spun in pilling tester for 4,500 revolutions at a constant speed of $30 \mathrm{rpm}$ to obtain fabric with pilling rate 1 (rate $1=$ maximum pill, rate $5=$ minimum pill), according to the standard test method ISO 12945.

\section{B. Ratio of Detergent to Fabric}

The amount of detergent used in this work was at the lowest amount that could completely remove oily stain (staining procedure was based on the standard test method AATCC 130) from polyester fabric through one washing cycle. It was found that the required ratio of detergent to fabric to water was $1 \mathrm{~g}$ : $6.5 \mathrm{~g}$ : $50 \mathrm{ml}$, respectively

\section{Ratio of Detergent to Enzyme}

Detergent and enzyme were mixed well at various weight ratios of $1: 0.05,1: 0.10,1: 0.15$, and 1:0.20, respectively, and they were used for washing test.

\section{Washing Procedure}

Solutions of detergent and detergent containing enzyme were prepared according to the ratios previously mentioned. Fabric was washed in the prepared solution at $35^{\circ} \mathrm{C}$ for 1 hour per cycle using a launder-o-meter "Gyrowash" as a washing tester. After each washing cycle, fabric was water rinsed for 30 minutes and then air dried. Both normal washing test (without stainless steel ball) and accelerated washing test (with stainless steel balls) were conducted. The accelerated washing was performed by adding 10, 20, 30 and 40 stainless steel balls to the test. It was found that the washing condition using 20 stainless steel balls showed the best pill removal efficiency (pilling rate of after washed fabric was rated 3-4, before washing was rated 1). Additional experiment was also done to determine the relationship between numbers of washing cycle when washing with and without stainless steel ball, by washing fabric (pilling rate 1) without stainless steel ball at $35^{\circ} \mathrm{C}$ for several cycles (1 hour per cycle) until the fabric pilling rate improved to $3-4$. It was found that 8 washing cycles at $35^{\circ} \mathrm{C}$ ( 1 hour per cycle) without stainless steel ball was comparable to 1 washing cycle using 20 stainless steel balls at same temperature and time per cycle.

\section{E. Fabric Testing}

1) Pilling rate

Fabric was evaluated for pilling rate by eye-comparing its surface appearance with 5 standard photographs of fabric (pilling rates 1 to 5 ) and grading to the nearest rate (i.e.1,2,3,4,5) or between two rates (i.e.1-2, 3-4), according to the standard test method ISO 12945-1. Fabric with pilling rate 1 is determined to have the highest amount of pills and fussy hairs while fabric with rate 5 has a smooth surface with the lowest amount of pills and hairs. Based on the requirement for exporting apparel to major markets, the pilling rate should be at least 3-4 [11].

2) Surface appearance

Fabric surface was observed under an optical microscope to determine for the amount of pill and hair contents.

\section{3) Color measurement}

Fabric before and after pilling as well as washing was measured for color values using a colorimeter Macbeth Color-Eye 7000 according to the AATCC Evaluation Procedure 6. Fabric color strength (K/S) or color depth was measured at fabric surface at wavelength $510 \mathrm{~nm}$ (red color) in which fabric with higher K/S showed darker color than that with lower K/S. In addition, fabric color difference $\left(\Delta \mathrm{E}^{*}\right)$, lightness $\left(\mathrm{L}^{*}\right)$ and color shade $\left(\mathrm{a}^{*}, \mathrm{~b}^{*}\right)$ were also measured. Fabric after pilling generally shows some color different from fabric before pilling because pills and fussy hairs on fabric surface are capable of changing the color appearance of fabric. On the contrary, when pills and hairs are removed, the color difference between fabrics should be minimized. In his work, fabric after pilling (both before and after washing) was color evaluated to see how much its color was different from that of fabric before pilling (pilling rate $5, \Delta \mathrm{E}^{*}=0$ ). The washing process that could produce fabric with $\Delta \mathrm{E}^{*}$ closed to 0 would be the optimal washing process for pill removal in this work. Measurement of fabric lightness and color shade was also done in order to respectively evaluate the brightest white $\left(\mathrm{L}^{*}=\right.$ $100)$ or darkest black $\left(\mathrm{L}^{*}=0\right)$ of fabric color as well as to see the color shade of fabric $\left(a^{*}>0\right.$ is red, $a^{*}<0$ is green, $b^{*}>0$ is yellow, $\mathrm{b}^{*}<0$ is blue, $\mathrm{a}^{*}=0$ and $\mathrm{b}^{*}=0$ is true neutral gray).

4) Weight loss

Fabric dry weight before and after washing was determined using an infrared balance in order to analyze for \% fabric weight loss after pill removal through washing.

5) Strength loss

Fabric was tested for bursting strength $(\mathrm{kPa})$ using a hydraulic-type bursting strength tester, according to the standard test method ASTM D 3786. Its strength before and after washing was measured and results were used for calculation of \% fabric strength loss after pill removal through washing.

\section{RESUlts AND DiscuSsion}

Originally spun polyester fabric had a pilling rate of 5 (lowest pill content) but after pilling, its pilling rate was down to 1 (highest pill content) shown as fabric (a) in Table I and in Fig. 1(a). When fabric with pilling rate 1 "fabric (a)" was washed with detergent at $35^{\circ} \mathrm{C}$ for 1 cycle (1 hour), the pilling rate of fabric still remained at 1 (see Table I and also Fig. 1 (b)) and this indicated that washing fabric (a) with detergent did 
not promote the pill removal at all.

Once fabric (a) was washed for 1 cycle with detergent containing various amounts of esterase enzyme, the fabric pilling rate or pilling resistance was improved and maximized to 2-3 when the ratio of detergent to enzyme of 1:0.10 was used for the washing process. This result confirmed that an addition of local produced esterase into the detergent could support the depilling efficiency of the detergent itself through enzyme catalyzing the hydrolysis of the polyester chains as already mentioned in the introduction. However, the required pilling rate for exported apparel was set at 3-4 [11] and this was also the target pilling rate of the fabric after washing in this work. Therefore, it could be concluded that the normal washing process (washing without stainless steel ball) using detergent: enzyme $1: 0.10$ at $35^{\circ} \mathrm{C}$ for more than 1 cycle was needed for increasing the fabric pilling rate to $3-4$. It was found that 8 normal washing cycles using detergent: enzyme 1:0.10 could increase the fabric pilling rate to $3-4$ and this result was comparable to one accelerated washing cycle using detergent: enzyme 1:0.10 and 20 stainless steel balls that could produce fabric with pilling rate 3-4 as shown in Table I and Fig. 1(d).

TABLE I: FABRIC PILLING RATE AND \% WEIGHT LOSS AFTER WASHING

\begin{tabular}{|c|c|c|}
\hline Fabric washing condition & Pilling rate & \% Weight loss \\
\hline Before pilling, no wash & 5 & - \\
\hline After pilling, no wash: fabric (a) & 1 & 0 \\
\hline Washing (a) with detergent & 1 & 0.73 \\
\hline $\begin{array}{l}\text { Washing (a) with detergent: enzyme } \\
\text { 1:0.05 }\end{array}$ & $1-2$ & 2.09 \\
\hline $\begin{array}{l}\text { Washing (a) with detergent: enzyme } \\
1: 0.10\end{array}$ & $2-3$ & 2.60 \\
\hline $\begin{array}{l}\text { Washing (a) with detergent: enzyme } \\
1: 0.15\end{array}$ & 2 & 2.52 \\
\hline $\begin{array}{l}\text { Washing (a) with detergent: enzyme } \\
1: 0.20\end{array}$ & 2 & 2.42 \\
\hline $\begin{array}{l}\text { Washing (a) with detergent: enzyme } \\
1: 0.10 \text { and } 10 \text { stainless steel balls }\end{array}$ & 2 & 2.44 \\
\hline $\begin{array}{l}\text { Washing (a) with detergent: enzyme } \\
1: 0.10 \text { and } 20 \text { stainless steel balls }\end{array}$ & $3-4$ & 2.78 \\
\hline $\begin{array}{l}\text { Washing (a) with detergent: enzyme } \\
1: 0.10 \text { and } 30 \text { stainless steel balls }\end{array}$ & $2-3$ & 2.16 \\
\hline $\begin{array}{l}\text { Washing (a) with detergent: enzyme } \\
1: 0.10 \text { and } 40 \text { stainless steel balls }\end{array}$ & $2-3$ & 2.59 \\
\hline $\begin{array}{l}\text { Washing (a) with detergent and } 10 \\
\text { stainless steel balls }\end{array}$ & 2 & 1.89 \\
\hline $\begin{array}{l}\text { Washing (a) with detergent and } 20 \\
\text { stainless steel balls }\end{array}$ & $2-3$ & 1.36 \\
\hline $\begin{array}{l}\text { Washing (a) with detergent and } 30 \\
\text { stainless steel balls }\end{array}$ & $2-3$ & 2.37 \\
\hline $\begin{array}{l}\text { Washing (a) with detergent and } 40 \\
\text { stainless steel balls }\end{array}$ & $2-3$ & 2.60 \\
\hline $\begin{array}{l}\text { Washing (a) with detergent: enzyme } \\
\text { 1:0.10 for } 8 \text { cycles }\end{array}$ & $3-4$ & 2.68 \\
\hline
\end{tabular}

Table I also showed slight fabric weight loss of 0.73-2.78\% after washing spun polyester fabric with detergent as well as with detergent containing enzyme. It was found that fabric washing with detergent containing enzyme lost more weight than fabric washing with only detergent. This weight loss could have come from loosing of fibers or from pill/hair removal during washing with detergent and esterase enzyme.

Results from Table I indicated that the optimal ratio between this alkaline powder detergent and the local produced alkaline cutinolytic esterase (PBURU-T5) should be at 1:0.10 and it's required for 8 normal washing cycles (1 hour/cycle) at $35^{\circ} \mathrm{C}$ for efficiently remove pills from spun polyester fabric (improve fabric pill resistance from pilling rate 1 to the required pilling rate 3-4) through washing with this optimal composition of detergent: enzyme mixture.

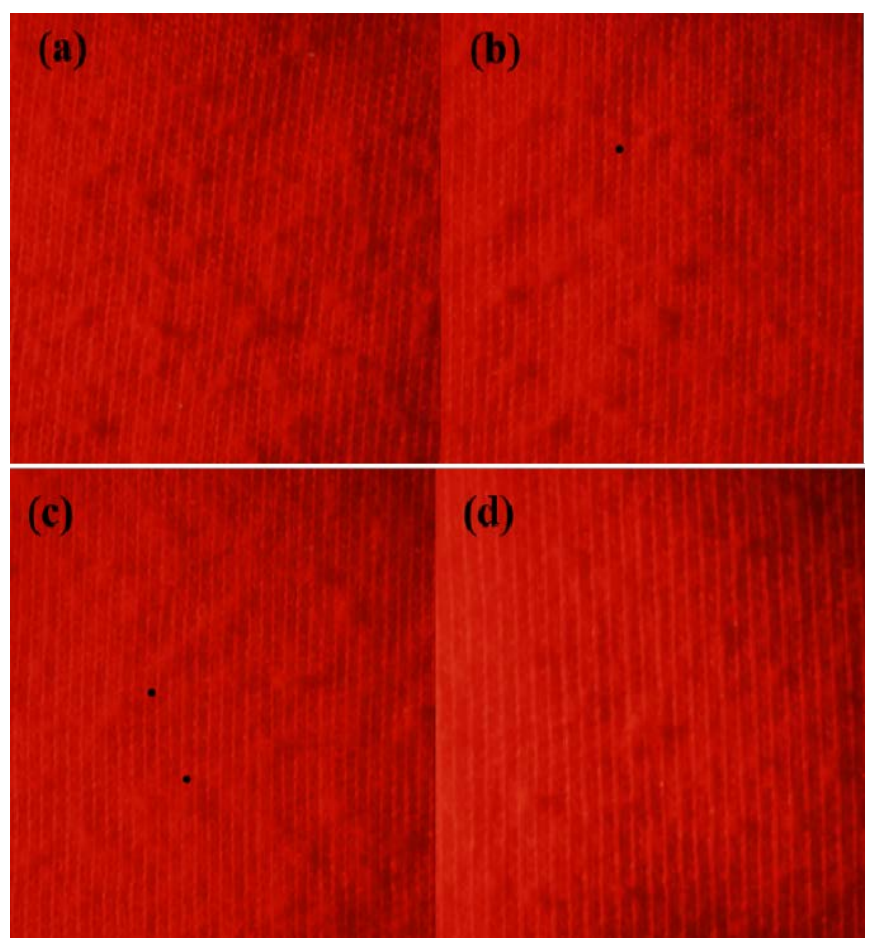

Fig. 1. Optical microscope images of fabric pills (a) after pilling/no wash, pilling rate 1 , (b) washing fabric (a) with detergent, pilling rate 1,(c) washing fabric (a) with detergent and 20 stainless steel balls, pilling rate 2-3, (d) washing fabric (a) with detergent: enzyme 1:0.10 and 20 stainless steel balls, pilling rate 3-4.

Table II Showed color values of fabric after pilling and after some washing conditions using detergent and detergent containing enzyme, comparison to color values of fabric before pilling. All fabrics in this Table showed similar yellowish red color $\left(\mathrm{L}^{*}, \mathrm{a}^{*}\right.$ and $\left.\mathrm{b}^{*}>0\right)$. Pilling and washing reactions did not change much of the lightness $\left(\mathrm{L}^{*}\right)$ and color shade ( $\mathrm{a}^{*}$ and $\mathrm{b}^{*}$ ) of fabrics. It was found that fabric before pilling had the lowest color strength $(\mathrm{K} / \mathrm{S}=24.4)$ or the lightest color. Once the fabric was pilled to rating 1 (fabric (a)), its color strength significantly increased 3 units $(\mathrm{K} / \mathrm{S}=27.4)$ to a darker shade and showed a noticeable color difference of $1.82\left(\Delta \mathrm{E}^{*} \geq 1\right.$, eyes detectable) when compared with the color of fabric before pilling $\left(\Delta \mathrm{E}^{*}=0\right)$. As fabric (a) with pilling rate 1 was washed with detergent as well as with detergent containing enzyme, the color strength (K/S) and color difference $\left(\Delta E^{*}\right)$ decreased from those of fabric (a) and the values were more closed to those of fabric before pilling (pilling rate $5, \mathrm{~K} / \mathrm{S}=24.4, \Delta \mathrm{E}^{*}=0$ ) than to those of fabric after pilling (no washing). This could be explained that washing fabric with detergent in the presence or absence of enzyme could promote the fabric pill removal and decrease the change of color appearance, with a higher efficiency of pill removal when detergent containing enzyme was used. It was clear to say that fabric washed with detergent: enzyme 1:0.10 (with and without 20 stainless steel balls) showed the lowest color strength and unnoticeable color difference $\left(\Delta \mathrm{E}^{*}<1\right)$ and 
the values were the closest to those of fabric before pilling, especially when washing fabric with detergent: enzyme 1:0.10 and 20 stainless steel balls. This could mean that an addition of esterase enzyme into the commercial detergent could assist the pill removal efficiency of the detergent itself.

TABLE II: FABRIC COLOR VALUES: LightNESS (L*), RED+/GREEN- (A*), Yellow+/Blue- $\left(\mathrm{B}^{*}\right)$, Color DifFerence $\left(\Delta \mathrm{E}^{*}\right)$ AND Color STRENGTH

\begin{tabular}{lccccc}
\multicolumn{1}{c}{$(\mathrm{K} / \mathrm{S})$} & & & & \\
\hline \multicolumn{1}{c}{ Fabric washing condition } & $\mathrm{L}^{*}$ & $\mathrm{a}^{*}$ & $\mathrm{~b}^{*}$ & $\Delta \mathrm{E}^{*}$ & $\mathrm{~K} / \mathrm{S}$ \\
\hline Before pilling, no wash & 36.6 & 55.5 & 29.4 & 0 & 24.4 \\
After pilling, no wash: fabric (a) & 36.8 & 55.8 & 30.3 & 1.82 & 27.4 \\
\hline Washing (a) with detergent & 37.1 & 56.4 & 30.5 & 1.51 & 26.8 \\
$\begin{array}{l}\text { Washing (a) with } \\
\text { detergent:enzyme 1:0.10 }\end{array}$ & 37.1 & 56.1 & 30.0 & 0.96 & 25.6 \\
$\begin{array}{l}\text { Washing (a) with } \\
\text { detergent:enzyme 1:0.10 and }\end{array}$ & 37.0 & 55.6 & 29.8 & 0.59 & 25.2 \\
$\begin{array}{l}\text { 20 stainless steel balls } \\
\begin{array}{l}\text { Washing (a) with detergent and } \\
\text { 20 stainless steel balls }\end{array}\end{array}$ & 37.2 & 55.7 & 29.7 & 1.10 & 25.9 \\
\hline
\end{tabular}

TABLE III: FABRIC BURSTING STRENGTH AND \% STRENGTH LOSS AFTER WASHING.

\begin{tabular}{lcc}
\hline \multicolumn{1}{c}{ Fabric washing condition } & $\begin{array}{c}\text { Bursting } \\
\text { strength } \\
(\mathrm{kPa})\end{array}$ & $\begin{array}{c}\% \text { Strength } \\
\text { loss }\end{array}$ \\
\hline $\begin{array}{l}\text { After pilling , no wash (pilling rate 1) } \\
\begin{array}{l}\text { After pilling (pilling rate 1) and washing with } \\
\text { detergent:enzyme 1:0.10 and 20 stainless } \\
\text { steel balls (pilling rate 3-4) }\end{array}\end{array}$ & 926 & 0 \\
\hline
\end{tabular}

Finally, the after washed fabrics were tested for their bursting strength shown in Table III and found that strength loss of $8 \%$ was observed when detergent: enzyme was used. However, polyester knitted fabric was considered to be one of the strongest fabrics in the world textile market. Its bursting strength was reported to be several times higher than fabrics made of viscose, acrylic, as well as cotton fibers [12]. Therefore, in this work the $8 \%$ bursting strength loss of polyester fabric after 8 normal washing cycles using detergent:enzyme 1:0.10 (one accelerated washing cycle using detergent:enzyme 1:0.10 and 20 stainless steel balls) was not a big concern for textile users.

\section{CONCLUSION}

This research discovered that a commercial detergent containing esterase could be used successfully for depilling of spun polyester knitted fabric (pilling rate 1) through 8 normal laundering cycles. The after washed fabric showed pilling rate of 3-4 with slight weight loss and strength loss.

\section{ACKNOWLEDGMENT}

Authors thank a research grant of Chulalongkorn University and the Department of Agriculture, Ministry of Agriculture and Cooperatives, Thailand for research supports.

\section{REFERENCES}

[1] Unilever, “Enzyme-containing surfactant compositions,” U.S. Patent 94 04771, 1994a.

[2] Unilever, "Eukaryotic cutinase variant with increased lipolytic activity," U.S. Patent 94 11303, 1994b.
[3] M. R. Egmond and C. J. van Bemmel, "Impact of structural information on understanding lipolytic function," IEEE Trans. Methods in Enzymology, vol. 284, pp. 119-129, 1997.

[4] J. S. Okkels, "Preparing polypeptide variants with improved functional properties,” U.S. patent 97 09664, 1997.

[5] B. K. Anderson, K. Borch, M. Abo, and B. Damgaard, "A method of treating polyester fabrics,” U.S. Patent 59 97584, 1999.

[6] M. Y. Yoon, J. Kellis, and A. J. Poulose, "Enzymatic modification of polyester,” IEEE Trans. AATCC Rev., vol. 2, pp. 33-36, 2002.

[7] S. G. Mccloskey and J. M. Jump, "Bio-polishing of polyester and polyester/cotton fabric,” IEEE Trans. Textile Research Journal, vol. 75 pp. 480-484, 2005.

[8] I. Donelli, P. Taddei, P. F. Smet, D. Poelman, V. A. Nierstrasz, and G. Freddi, "Enzymatic surface modification and functionalization of PET: A water contact angle, FTIR, and fluorescence spectroscopy study,” IEEE Trans. Biotechnology and Bioengineering, vol 103, pp. 845-856, 2009.

[9] T. Nimchua, D. E. Eveleigh, U. Sangwatanaroj, and H. Punnapayak, "Screening of tropical fungi producing polyethylene terephthalate-hydrolyzing enzyme for fabric modification,” IEEE Trans. Journal of Industrial microbiology and Biotechnology, vol. 35, pp. 843-850, 2008.

[10] G. M. Guebitz and A. Cavaco-Paulo, "Enzymes go big: Surface hydrolysis and functionalisation of synthetic polymers," IEEE Trans. Trends in Biotechnology, vol. 26, pp. 32-38, 2008.

[11] Textiles, Carpet, Feather and Down Testing Price List, Intertek Testing Services Ltd., Shanghai, China, 2008, pp. 1-31.

[12] Z. Degirmenci and E. Coruh, "The influences of loop length and raw material on bursting strength air permeability and physical characteristics of single jersey knitted fabrics," IEEE Trans. Journal of Engineered Fibers and Fabrics, vol. 12, pp. 43-49, 2017.

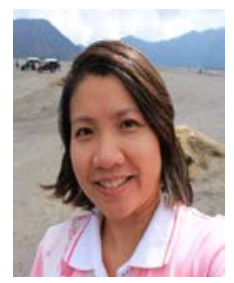

Taweeporn Sooksai is currently a full time $\mathrm{PhD}$ candidate in Biotechnology, Faculty of Science, Chulalongkorn University. She has been working as a scientist at the Department of Agriculture, Ministry of Agriculture and Cooperative, Thailand for almost 5 years. Her research interests are in the areas of biotechnology and postharvest technology.

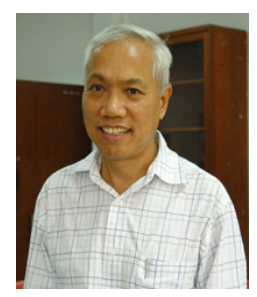

Hunsa Punnapayak is a professor of the Department of Botany, Faculty of Science, Chulalongkorn University. His research interests include biomass and crop residue utilization, biotransformation, fungal enzymes and fermentation. He has published more than 34 academic papers with 289 citations.

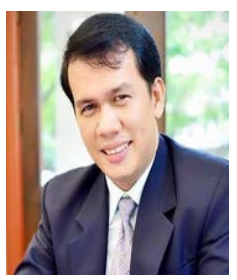

Sehanat Prasongsuk is an associate professor of the Department of Botany, Faculty of Science, Chulalongkorn University. His research interests include Plant and Fungal Biotechnology, Plant and Crop Residues utilization, Fungal enzymes and metabolites, Mushroom and its Applications and Biopulping and Biobleaching. He has published more than 26 academic papers with 172 citations.

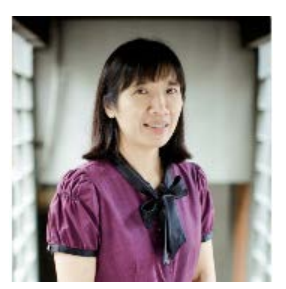

Usa Sangwatanaroj is an assistant professor of the Department of Materials Science, Faculty of Science, Chulalongkorn University. Her research interests include productions and applications of enzymes for textile applications (retting, desizing, scouring, bio-stoning, and depilling), bacterial decolorization of dye effluent, as well as natural dyeing of cotton and silk. 


\section{Applied Chemistry and Microcapsule Technology}


